\title{
Evaluation of Seismic Performance of Improved Rocking Concentrically Braced-frames with Zipper Columns
}

\author{
Nasim Irani Sarand ${ }^{1 *}$, Abdolrahim Jalali ${ }^{1,2}$ \\ ${ }^{1}$ Department of Civil Engineering, Faculty of Civil Engineering, University of Tabriz, 5166616471 Tabriz, 29 Bahman Blvd., Iran \\ 2 Department of Civil Engineering, Faculty of Engineering, University of Kyrenia, Girne,99320 Mersin 10, Turkey \\ * Corresponding author, e-mail: nasimirani@tabrizu.ac.ir
}

Received: 01 October 2019, Accepted: 24 February 2020, Published online: 26 March 2020

\begin{abstract}
Concentrically braced frames (CBFs) as one of well-known stiff and common lateral force resisting systems often show limited ductility capacity under severe earthquakes. This study proposes rocking zipper braced frame (RZBF) to improve the drift capacity of CBFs which is based on combination of rocking behavior and zipper columns. In the RZBF system, rocking behavior permit the braced frame to uplift during the earthquake and then restoring force induced through post-tensioned bars self-center the frame to its initial state. Also, zipper columns can decrease the concentration of damage by distributing the unbalance force at the mid bay over the frame's height. To assess the performance of RZBF, a comparison study is carried out considering CBF, rocking concentrically braced frame, zipper braced frame and RZBF. For this purpose, some frames structures are designed and nonlinear time history analysis conduct under a set of earthquake records. Seismic responses such as roof drift ratio, gap opening at the column-base interface, forces of top story braces and post-tensioned bars are taken into consideration. The results show that the proposed RZBF has better performance among the others and zipper columns can improve the behavior of rocking systems.
\end{abstract}

\section{Keywords}

seismic performance, rocking system, zipper column, self-centering, nonlinear time history analysis

\section{Introduction}

Concentrically Braced Frames (CBFs) are the most widely used lateral load resisting systems which provide great stiffness and ordinary ductility. But under severe earthquakes, CBFs may have undesirable response like concentration of damage within a single story and soft story mechanism can be formed $[1,2]$. There are several studies that were conducted to improve the seismic performance of $\mathrm{CBF}$ such as designing CBFs with new proposed methods [3-6] using Buckling-Restrained Braced Frames (BRBFs) [7, 8], Zipper Braced Frames (ZBF) [9] and Rocking Concentrically Braced Frame (RCBF) [10, 11]. In the CBFs, seismic energy was dissipated by yielding of the braces under tension with elastic behavior in beams and columns. Costanzo et al. [4] assessed the adequacy of two different codes (European code (EC8) [12] and AISC34-10 Seismic Provision [13]) on the designing of the beams of the braced frames. Results showed that designing frames according to AISC341 leads to more uniform story drift distribution comparing to EC8. Reduced Section Solution (RSS) was suggested by Giugliano et al. [6] as a novel method for designing braces.
According to the results, this new method would have influence on improving the seismic performance and utilizing RSS method, resulted in savings in the weight of constructional steel. Longo et al. [5], proposed the design methodology considering the Theory of Plastic Mechanism Control (TPMC), for dual systems which consist of moment-resisting frame and CBF. Results indicated that seismic performance was improved using TPMC. Merczel et al. [2, 14] performed different studies on the seismic behavior of CBF under different ground motions. Several frames were designed using Euro code provisions. The results of nonlinear time history analysis showed the formation of weak story mechanism. The effects of brace behavior and plastic deformation of diagonals on the formation of weak story mechanism was studied [2, 14]. Merczel et al. conducted a comprehensive study on CBF behavior focusing on the weak story behavior. Their study consist two primary parts: identifying parameters which have influences on forming weak story mechanism and improving the Euro code 8 by impeding formation of weak stories [15]. 
The BRBF is an improved case of CBF showing desirable energy dissipating performance [7]. This system forms from two primary components: steel core blocked by a hollow steel section and confining element which prevent the buckling of the core. Naghavi et al. [16] found that energy dissipating in CBF system is about $20 \%$ of the BRBFs which demonstrates larger ductility and energy dissipation via inelastic behavior for BRBF system [16]. Sabelli et al. [17] presented that BRBFs had better behavior in terms of inter story drifts comparing with CBFs. However, due to low post-yield stiffness of the braces, BRBFs are prone to have undesirable large drifts [18-21]. Khatib et al. [22] proposed adding zipper columns to overcome forming soft story mechanism which occurs in the ordinary CBF. Zipper columns lead to mobilize the stiffness of the braces those left and all the beams to bear vertical unbalanced force. Zipper columns are elements which link the intersection point of the beam and brace at the midpoint of the bay and as consequence redistribute the unbalanced force to the braces that are upon the threshold of buckling. By this way, damage concentration at one story stretched out the frame height. In this relation, a study on the design and behavior of the ZBF had been accomplished by Sabelli et al. [23]. Results indicate the adequacy of zipper columns in uniformly distributing the inter story drift over the height of the frame [23]. A method for predicting the design axial forces in zipper braced frames was developed by Tremblay and Trica [24]. According to the proposed method, under severe ground motions, zipper columns remain elastic and prevent initiating story mechanism [24]. The effects of the building height and ground motion type on the seismic behavior of ZBFs were studied by Trica and Tremblay [25]. Results showed that for ordinary ground motions, frames with different heights have satisfactory performance, however, under near fault ground motions, taller frames experienced collapse due to dynamic instability [25]. In order to better assess the seismic performance of the ZBF, an incremental dynamic analysis was performed by Trica and Tremblay [26]. The results showed that global dynamic instability took place at the same time or shortly after reaching to the collapse prevention limit state [26]. Also, Yang et al. [1] proposed the refined design procedure for modified zipper braced frame consisting of zipper columns and the hat truss. Zipper columns force braces to buckle at the same time except top story braces and the hat truss supply large deformation capacity and impeded the creation of a full plastic mechanism [1]. However, modified
ZBFs were not economical in high-rise buildings as they needed extremely large cross sections for top story braces. In this relation, Ozcelik et al. [27] showed that CBF has better performance than modified ZBF in terms of column axial load demand in the case of high rise buildings.

Recently, rocking systems have been used as a new lateral force resisting system which concentrate damage in replaceable elements and reduce residual drifts noticeably $[9,10]$. Generally, rocking systems are consist of uplifting joints and post-tensioned cables which provide rocking behavior and restoring force, respectively. First studies about rocking systems were presented by Huckelbridge and Clough on a three story frame which had rocking joints at the column bases [28]. Also, Kelly and Tsztoo [29] conducted study on using yielding cables and rocking behavior together in order to dissipate energy as columns uplift. Rocking systems due to having near zero residual drift and enhanced drift capacity and ductility have been taken in to consideration as lateral load resisting system $[10,11,30,31]$.

$\mathrm{Wu}$ and $\mathrm{Lu}$ [32] suggested light-weight energy-dissipation rocking core frame as a novel lateral load resisting system that has improved seismic performance in terms of low residual drifts due to utilizing self-centering energy-dissipation braces. Blebo and Roke proposed seismic-resistant self-centering rocking core system to provide considerable drift capacity while limiting residual drift and structural damage [33, 34]. Grigorian and Griogorian [35] proposed structural design of rocking wall-frame which have uniform drift distribution and lead to prevention of soft story mechanism formation. Mottier et al. [36], use rocking systems in the retrofitting of existing steel structures. Jia et al. [37] suggested rocking dual-steel has trilinear hysteretic behavior and lead to mitigation of residual drift as a result of early re-yielding of low-yield point steel. The results of Moradi and Burton [38] showed that the seismic response of the controlled rocking steel braced frames do not affect considerably by changing design parameters such as post-tensioned bars modulus of elasticity and strain hardening ratio of the fuses.

Rocking Concentrically Braced Frame (RCBF) is one type of the rocking system that has been proposed in the past decade as high performance lateral load resisting system for steel structures. The rocking behavior at the base causes the larger lateral displacement and limited member force demand as a result of softening mechanism of the RCBFs [39]. Also, RCBF experiences first damage at higher drifts comparing with CBF system, resulting in 
better seismic performance in terms of drift ratio and residual drift as presented in different experimental and analytical studies [10, 40]. Recent studies presented that RCBFs like rocking concentrically braced frame [10, 41, 42], dual rocking frames [31, 43, 44], using multiple rocking joint through the height of the frame [11], rocking braced frames with energy dissipating elements and various story numbers [45] and tension-only concentrically braced frames with rocking core [46] are able to decrease damage under severe earthquakes and enhance the seismic performance of ordinary CBFs in terms of uniform distribution of inter story drifts. Huang et al. showed that RCBFs are economically better systems comparing to CBFs for low and mid-rise building under severe earthquakes [47]. Despite several studies on the different types of RCBF, this system may experience unbalance force concentration in the braces of top stories [10]. For further improving the behavior of RCBF in terms of distribution of the unbalanced force, in this study zipper columns are proposed to utilize at the mid bay of RCBF system. In the proposed Rocking Zipper Braced Frame (RZBF), zipper columns connect the mid bays together and transmit the undesired unbalance force. In order to evaluate the seismic performance of RZBF, a comparative study with other archetypes (CBF, $\mathrm{ZBF}, \mathrm{RCBF}$ ) under a set of far field ground motions is carried out considering different seismic responses such as roof drift ratio, residual roof drift ratio, gap opening, force of post-tensioned bars and top story braces.

\section{Methodology}

In order to evaluate the seismic performance of RZBF, four story office buildings with different configurations were designed and nonlinear time history dynamic analyses were conducted using OpenSees [48].

\subsection{Frame configuration}

Fig. 1 presents four different configurations that are studied in this paper. As presented in Fig. (1), parts (a) to (d) show a $\mathrm{CBF}$, a ZBF with a hat truss, a rocking concentrically braced frame with Post-Tensioned (PT) bars at the mid bay (RCBF), and rocking braced frame with zipper columns and PT bars at the midpoint of the bay (RZBF), respectively. RZBF is a modified model of RCBF which has zipper columns. The aim of using zipper column is to redistribute the unbalance force of the mid bay over the different stories and prevent the damage concentration in one story. Both rocking frames have a horizontal base element which located between the column bases of rocking frame columns.
This base strut conveys the base shear from the uplifted column to the column in contiguity with the foundation. Also, they have two additional gravity columns adjacent to the rocking frame, which tend to distribute the gravity load caused by rocking of the system. Additionally, there are Energy Dissipating (ED) elements between the adjacent gravity columns and rocking frame columns. Due to increase the dissipating energy in higher modes, ED elements are located over the height of the frame.

\subsection{Prototype structure}

The floor plans of prototype structure consist of 6 bays in width and length (as presented in Fig. 1(e)). The bay length is $9.15 \mathrm{~m}$, the height of first story is $4.5 \mathrm{~m}$ and the other stories height is $3.9 \mathrm{~m}$. Dead load plus the weights of partitions constitute the seismic mass. The tributary seismic mass values for the first, second, third and roof stories are $378000,375000,375000$ and $258000 \mathrm{Kg}$, respectively.

\subsection{Design of archetypes}

Rocking frames were designed according to the limit state method proposed by Roke et al. [10]. The design procedure is the same as response spectrum analysis design one with some modifications in order to consider unique behavior of the rocking braced frames. In the proposed method, the performance objectives are immediate occupancy under design-based earthquakes and the collapse prevention under maximum considered earthquakes. The design procedure is presented in Fig. 2. The utilized codes are "AISC load and resistance factor design" [49] procedure and "Seismic provisions for structural steel buildings" [13]. A design acceleration spectrum $\left(\mathrm{SA}_{\mathrm{DS}}\right)$ is generally determined assuming $5 \%$ for damping ratio. The Spectral Acceleration (SA) at periods of 0.2 second (SS) and SA at a period of 1 second (S1) is $1.5 \mathrm{~g}$ and $0.6 \mathrm{~g}$, respectively. The site class considered to be class D and

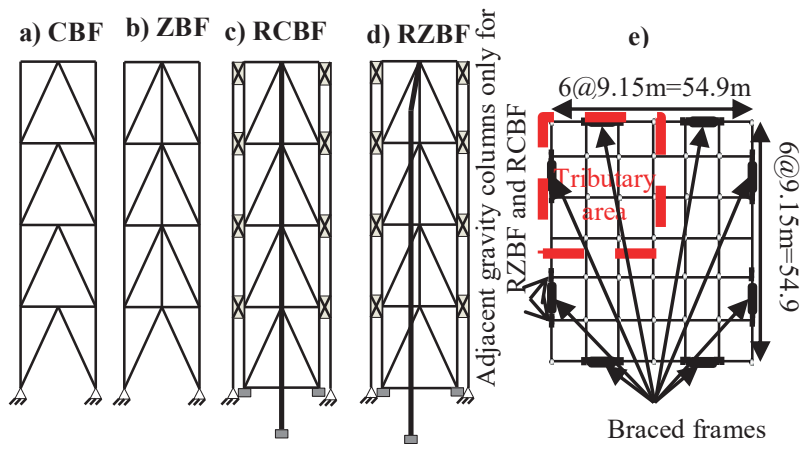

Fig. 1 Archetypes configuration (a) CBF, (b) ZBF, (c) RCBF, (d) RZBF, (e) Floor plan for prototype structure 


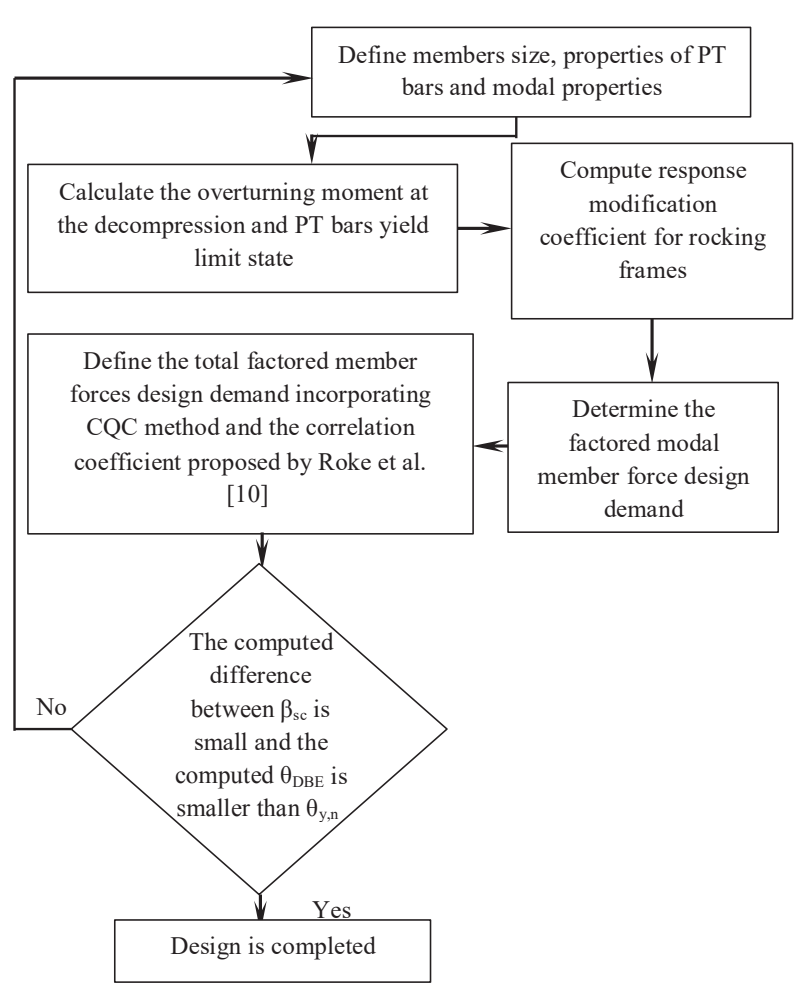

Fig. 2 Procedure of design method used for rocking frames

the long-period transition period (TL) assumed to be 8 . So, in order to define the $\mathrm{SA}_{\mathrm{DS}}$ for Design Basis Earthquake (DBE), the mentioned parameters were used.
For all the frames the bay length is $9.15 \mathrm{~m}$, the first story and the other stories height are $4.5 \mathrm{~m}$ and $3.9 \mathrm{~m}$, respectively. Design steel yield strength, the modulus of elasticity and Poisson ratio are set to be $345 \mathrm{MPa}, 200 \mathrm{GPa}$ and 0.3 , respectively. For PT bars, the modulus of elasticity was $205 \mathrm{GPa}$, the design yield strength and ultimate strength are $454 \mathrm{kN}$ and $567 \mathrm{kN}$, respectively and the Poisson ratio is 0.3 . The initial PT bar forces are considered to be $40 \%$ of the yield strength for both types. The member sizes for the designed frames are given in Tables 1 to 2 . The periods and mass participation ratios are presented in Table 3.

\subsection{Analytical model}

The seismic behaviors of the archetypes are assessed by nonlinear time history analysis. A two dimensional model of the analytical models are presented in Fig. 3(a). In the rocking systems, connections at the base nodes were modeled using Elastic Perfectly Plastic Gap element with elastic-no-tension materials in horizontal and vertical directions. ED elements were modeled using ElasticPP material parallel with elastic material. In the numerical model, the base vertical and horizontal gap connection is shown by springs in Fig. 3(b). Leaning columns (LC) were used to model the $P-\Delta$ effects. Elastic-beam-column elements were used for modeling of these LCs. To model structural elements like beams,

Table 1 Member size for $\mathrm{CBF}$ and $\mathrm{ZBF}$

\begin{tabular}{|c|c|c|c|c|c|c|c|}
\hline & & $\mathrm{CBF}$ & & & $\mathrm{ZBF}$ & & \\
\hline Story & Column & Beam & Brace & Column & Beam & Brace & Zipper column \\
\hline 1 & W10X106 & W12X106 & W12X120 & W12X136 & W10X60 & W12X190 & - \\
\hline 2 & W10X106 & W12X96 & W12X96 & W12X120 & W10X60 & W12X96 & W12X58 \\
\hline 3 & W12X96 & W12X96 & W12X106 & W12X106 & $\mathrm{W} 12 \mathrm{X} 120$ & W12X120 & W12X106 \\
\hline 4 & W12X96 & W12X96 & W12X87 & W12X58 & W8X48 & W12X120 & W12X152 \\
\hline
\end{tabular}

Table 2 Member size for RCBF and RZBF

\begin{tabular}{|c|c|c|c|c|c|c|c|}
\hline & & $\mathrm{RCBF}$ & & & RZBF & & \\
\hline Story & Column & Beam & Brace & Column & Beam & Brace & Zipper column \\
\hline 1 & $\mathrm{~W} 12 \mathrm{X} 170$ & W12X106 & $\mathrm{W} 12 \mathrm{X} 170$ & W14X283 & W10X60 & W12X152 & - \\
\hline 2 & $\mathrm{~W} 10 \mathrm{X} 170$ & W12X96 & W12X106 & W14X283 & W10X60 & $\mathrm{W} 12 \mathrm{X} 120$ & W12X106 \\
\hline 3 & W12X106 & W12X96 & W12X152 & W12X106 & W12X120 & W12X170 & W12X136 \\
\hline 4 & W12X106 & W12X96 & W12X106 & W12X58 & W8X48 & W14X211 & W12X152 \\
\hline
\end{tabular}

Table 3 Periods and mass participation ratios

\begin{tabular}{|c|c|c|c|c|c|c|c|c|}
\hline \multirow[b]{2}{*}{ Mode } & \multicolumn{2}{|c|}{$\mathrm{CBF}$} & \multicolumn{2}{|c|}{$\mathrm{ZBF}$} & \multicolumn{2}{|c|}{$\mathrm{RCBF}$} & \multicolumn{2}{|c|}{ RZBF } \\
\hline & $T_{n}(\mathrm{sec})$ & $M_{n} / M_{\text {total }}$ & $T_{n}(\mathrm{sec})$ & $M_{n} / M_{\text {total }}$ & $T_{n}(\mathrm{sec})$ & $M_{n} / M_{\text {total }}$ & $T_{n}(\mathrm{sec})$ & $M_{n} / M_{\text {total }}$ \\
\hline 1 & 0.447 & 0.77 & 0.418 & 0.79 & 0.492 & 0.78 & 0.467 & 0.8 \\
\hline 2 & 0.158 & 0.15 & 0.147 & 0.14 & 0.1433 & 0.14 & 0.137 & 0.13 \\
\hline 3 & 0.091 & 0.064 & 0.0783 & 0.056 & 0.0821 & 0.063 & 0.0722 & 0.055 \\
\hline 4 & 0.0691 & 0.02 & 0.0644 & 0.018 & 0.0603 & 0.02 & 0.0534 & 0.015 \\
\hline
\end{tabular}




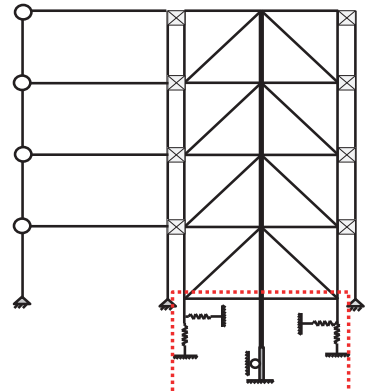

(a)

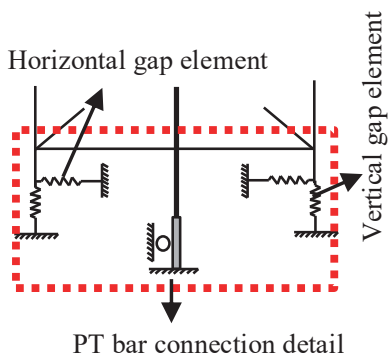

(b)
Fig. 3 Schematic picture of numerical model for rocking frames (a) elevation view, (b) details of boundary conditions for vertical gap, horizontal gap and PT bars connections

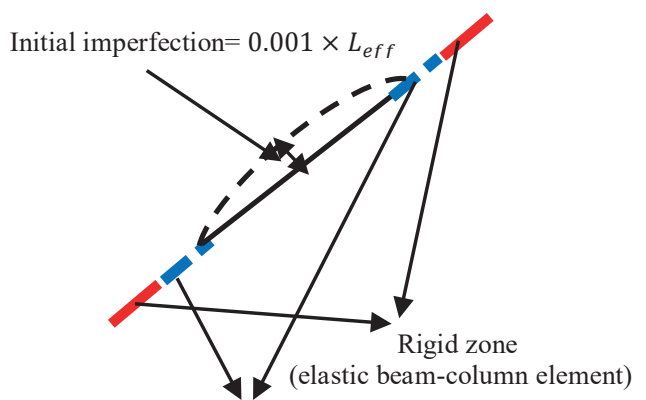

Hinge zone (force-based beam-column element)

Fig. 4 Numerical model for gusset plate

columns and braces, forced-based nonlinear beam-column elements with four integration points and steel02 material for fiber sections were used. In order to model the gradual yielding of wide flange sections, eight and four fibers were used over the height of web and through the flange thickness, respectively. Beam-column connections in the rocking frames were shear tab types that in the numerical modeling concentrated rotational spring element was used [50].

To accurately model the buckling behavior of braces, braces are divided in to 10 nonlinear beam-column elements with three integration points [51]. The initial imperfection used in the modeling was 0.001 of its effective length.
Beam-column connections for the $\mathrm{CBF}$ and ZBF systems considered to be pin, however, for the RCBF and RZBF systems shear tab types were used. PT bars were modeled using corotational truss elements with a combined material using elastic perfectly plastic and hardening materials to simulate the tension-only behavior. For modeling brace to the beam-column connections, gusset plates were used. In other words, the brace connections consist of two parts: rigid zone at the intersection of beam-column-brace and hinge zone (Fig. 4).There are several modeling method for gusset plates such as rotational springs $[52,53]$ and force-based fiber elements [54]. In modeling of gusset plates, combination of elastic beam-column element and force-based beam-column element with two integration points were used.

\subsection{Ground motion records}

A series of seven scaled ground motions with design-based earthquake level is used to evaluate the seismic performance of the different archetypes. The method proposed by Seo et al. [55] was used to scale the ground motions to the DBE level. Rayleigh damping with a $5 \%$ damping ratio in the first and third modes was used. The properties of ground motions are tabulated in Table 4.

\section{Results and discussions}

\subsection{Validating the numerical model}

In order to validate the accuracy of modeling for rocking systems, at first the 0.6-scale experimental frame proposed by Sause et al. [56] were modeled. The section properties, numerical model and the test structure are shown in Fig. 5(a) to (c), respectively. The seismic mass from the first story to the roof, are: $135900 \mathrm{~kg}, 134800 \mathrm{~kg}, 134800 \mathrm{~kg}$, and $142200 \mathrm{~kg}$, respectively. The tributary gravity loads of the test structure from the first story to the roof, are: $1495 \mathrm{kN}$, $1484 \mathrm{kN}, 1484 \mathrm{kN}$, and $1556 \mathrm{kN}$, respectively. The gravity columns and base strut sections of the test structure are

Table 4 Properties of ground motion set

\begin{tabular}{|c|c|c|c|c|c|c|c|c|}
\hline Records & Event & Year & Station & Fault type & Magnitude & Component & Dist (Km) & Scale Factor \\
\hline G1 & $\begin{array}{l}\text { Mammoth } \\
\text { Lake-01 }\end{array}$ & 1980 & Long Valley Dam & $\begin{array}{l}\text { Normal } \\
\text { Oblique }\end{array}$ & 6.06 & 000 & 12.56 & 1.49 \\
\hline $\mathrm{G} 2$ & Loma Prieta & 1989 & $\begin{array}{l}\text { Bear Valley \#10 } \\
\text { Webb Residence }\end{array}$ & $\begin{array}{l}\text { Reverse } \\
\text { oblique }\end{array}$ & 6.93 & 220 & 66.89 & 2.30 \\
\hline G3 & Northridge & 1994 & LA-Saturn St & Reverse & 6.69 & 020 & 21.17 & 1.03 \\
\hline G4 & Northridge & 1994 & $\begin{array}{c}\text { Rinaldi Receiving } \\
\text { Station }\end{array}$ & Reverse & 6.69 & 228 & 6.5 & 0.55 \\
\hline G5 & Kobe & 1995 & Amagasaki & Strike Slip & 6.9 & 000 & 11.34 & 1.03 \\
\hline G6 & Kobe & 1995 & Kakogawa & Strike Slip & 6.9 & 000 & 22.5 & 1.95 \\
\hline G7 & Kocaeli & 1999 & Fatih & Strike Slip & 7.51 & 000 & 53.34 & 2.63 \\
\hline
\end{tabular}




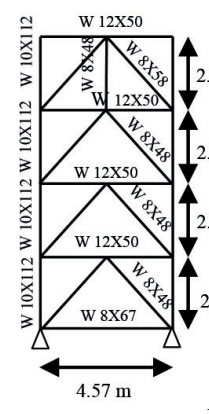

(a)

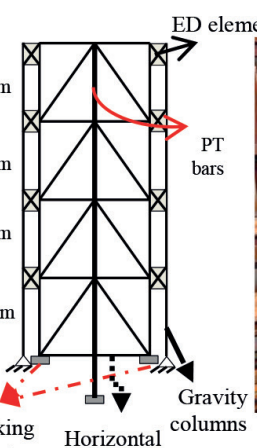

(b)

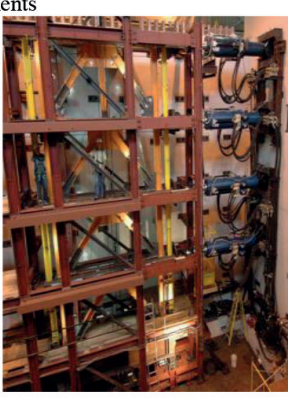

(c)
Fig. 5 (a) Section properties of the test structure, (b) Numerical model, (c) Test structure [56]
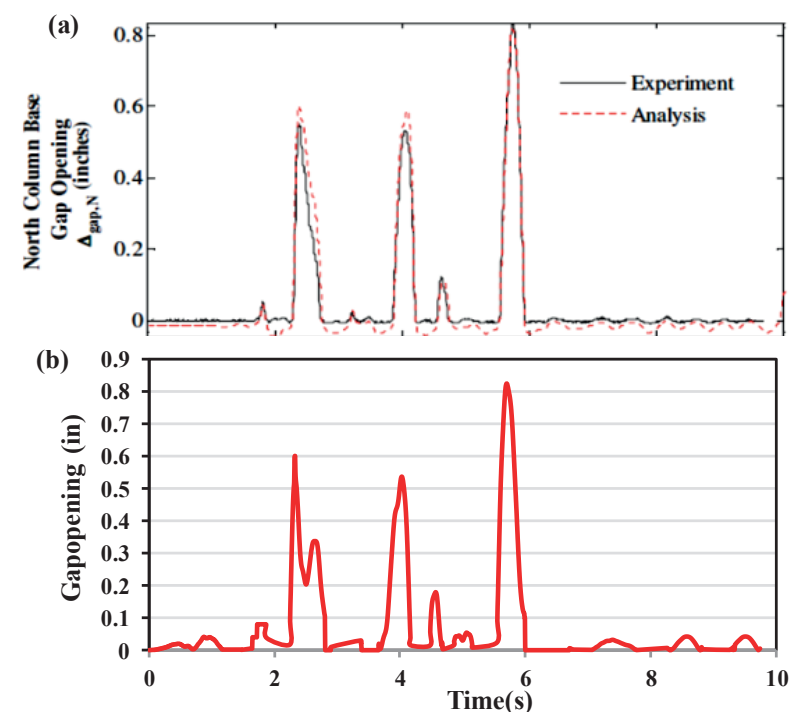

Fig. 6 Gap opening (a) Experimental result [56], (b) Numerical result

(a)
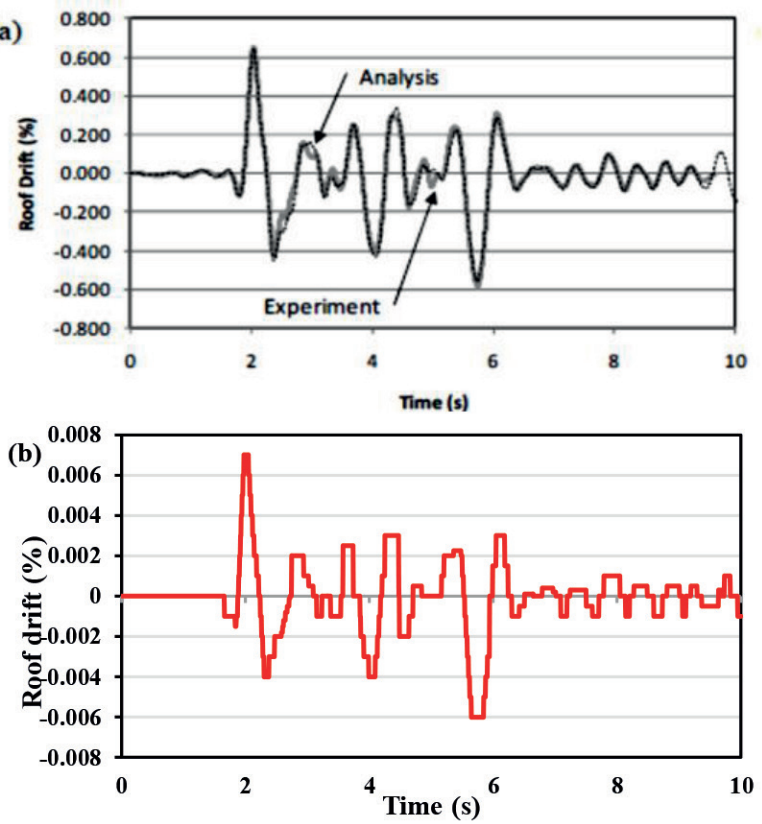

Fig. 7 Roof drift ratio (a) Experimental result [56], (b) Numerical result
W8X67 and W36X230, respectively. The comparison of the result of the analytical model and experimental test is given in Figs. 6 and 7 which the experimental results and numerical results are shown in black and red, respectively. It is observed good agreement between the experimental result and numerical model.

\subsection{Roof drift ratio and residual drift}

The time histories of roof drift ratio for each frame is shown typically in Fig. 8. Rocking frames have larger peak roof drifts comparing with the $\mathrm{CBF}$ and $\mathrm{ZBF}$ due to reduced stiffness after decompression of column. The mean values of roof drift for RCBF and RZBF is almost 2 times larger than the mean values for the $\mathrm{CBF}$ and ZBF. Also, according to Fig. 8, RCBF and RZBF have less residual roof drifts comparing with $\mathrm{CBF}$ and $\mathrm{ZBF}$ which indicate the better seismic performance for these systems. This result is in line with the results of previous studies [43]. A comparison between roof drift ratios for different archetypes under different records presented in Fig. 9. The maximum roof drift ratio for CBF, ZBF, RCBF and RZBF is $0.62,0.993,1.63$ and $1.74 \%$, respectively.

Fig. 10 shows the residual story drifts of the archetypes. By dividing the difference in residual displacements of adjacent floors by the story height, residual story drifts

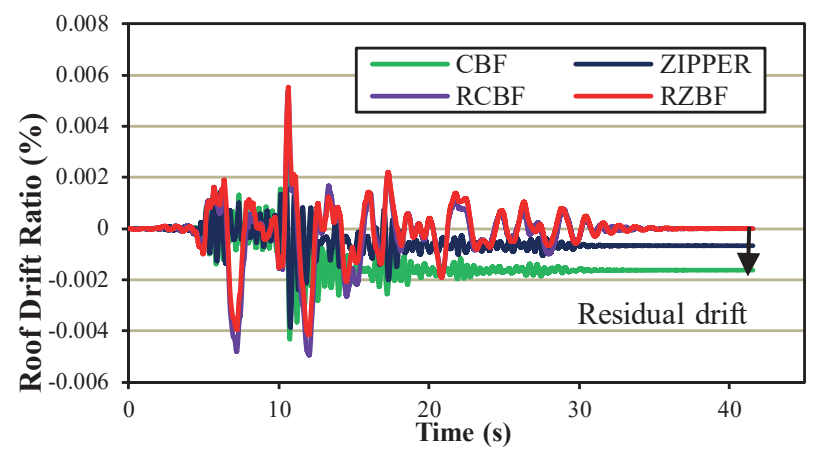

Fig. 8 Roof drift ratio under G4 record

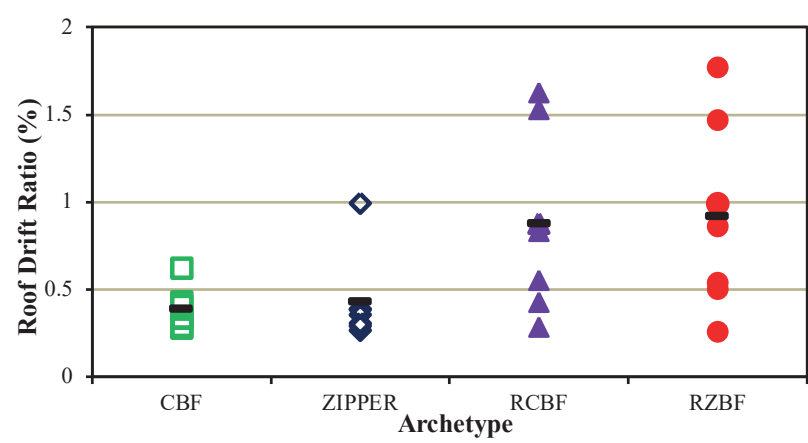

Fig. 9 Comparison between roof drift ratio of archetypes under different records 


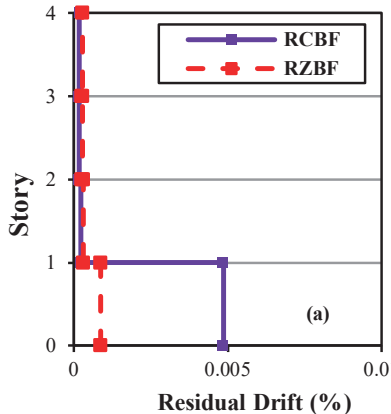

(a)

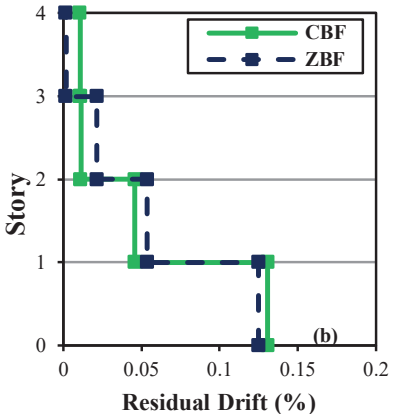

(b)
Fig. 10 Comparison between residual story drift mean values of different archetype (a) rocking frames, (b) fixed base frames

were calculated. As shown in Fig. 10, the CBF and ZBF experience larger residual drifts comparing with the RCBF and RZBF. In the other words, the mean values of residual story drift of rocking frames are considerably smaller than the mean values of residual drifts for the fixed base frames. The values of residual roof drifts for different archetypes are shown in Table 5. Seismic analyses show that the RZBF practically eliminates residual roof drift which sustains small residual drifts due to plastic deformations at the column bases. The mean value of residual roof drift for the RCBF and RZBF is 0.0014 and 0.00016 radians, which showed the reliable self-centering behavior of these frames. This result is identical with the result of past researches $[40,43,44]$. They presented that the residual roof drift for fixed base frame is 46 and 54 times larger than the residual roof drift for rocking frame under DBE and MCE earthquakes, respectively. The results show RZBF system has less residual drift comparing with the RCBF system indicating effect of zipper columns in enhancing seismic behavior of RZBF in terms of residual drift.

The roof displacement time histories of different archetypes are presented typically in Fig. 11. As mentioned earlier, ED elements used in rocking systems to dissipate

Table 5 Residual roof drifts for archetypes (radian)

\begin{tabular}{lcccc}
\hline Record & \multicolumn{4}{c}{ Archetypes } \\
& CBF & ZBF & RCBF & RZBF \\
\hline G1 & 0.00977 & 0.00521 & 0.00021 & 0.000113 \\
G2 & 0.0183 & 0.00767 & 0.00009 & 0.0000479 \\
G3 & 0.162 & 0.0666 & 0.000032 & 0.000113 \\
G4 & 0.1021 & 0.2016 & 0.000113 & 0.0000995 \\
G5 & 0.04 & 0.0258 & 0.00003007 & 0.000161 \\
G6 & 0.0068 & 0.0154 & 0.00938 & 0.000591 \\
G7 & 0.015 & 0.0116 & 0.000000273 & 0.000000464 \\
Mean & 0.050567143 & 0.047697143 & 0.001407906 & 0.000160838 \\
\hline
\end{tabular}

energy during earthquakes. According to Fig. 11, responses of rocking frames damped out more rapidly than the fixed base frames. In other words, amplitude of roof drift ratio is reduced by ED elements. This result is in line with the results presented by Dyanati et al. [40]. As shown in Fig. 11, the residual displacement of $\mathrm{ZBF}$ is $60 \%$ less than $\mathrm{CBF}$ which indicate the effect of zipper columns on improving the seismic behavior in terms of residual drifts.

According to Fig. 12 section (a) all the archetypes experience almost same mean values in term of first story drift ratio. The mean value of first story drift ratio for $\mathrm{CBF}$, $\mathrm{ZBF}, \mathrm{RCBF}$ and RZBF is $0.608,0.799,0.618$ and $0.637 \%$, respectively. However, in the other stories, rocking frames have larger inter story drift ratio comparing with fixed based frames and distribution of inter story drift ratio is more uniform in rocking frames. This outcome is similar to the results of Rahgozar et al. [43].

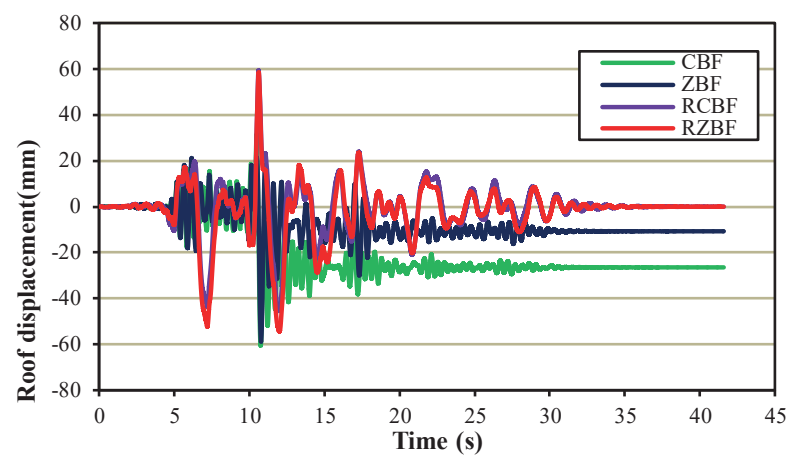

Fig. 11 Time histories of roof displacements under G4 record
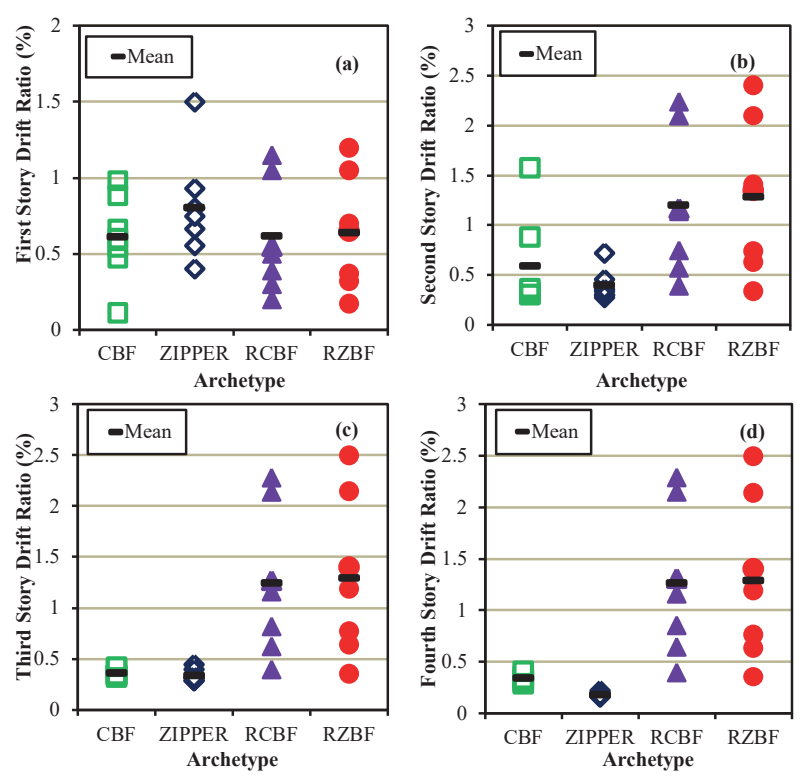

Fig. 12 Variation of drift ratios for different archetypes under suite of earthquake ground motions (a) first story, (b) second story,

(c) third story, (d) fourth story 


\subsection{Force of top story brace}

Forces of top story braces represent the responses of PT bars forces, zipper columns and inertial forces of the roof. The typical time histories of top story braces force are given in Fig. 13. RZBF has the lowest brace force at each record, since the PT bars transform the brace forces and zipper columns distribute the unbalance force over the stories. For instance, the maximum brace force under G4 record for $\mathrm{CBF}, \mathrm{ZBF}, \mathrm{RCBF}$ and $\mathrm{RZBF}$ is $2114,1667,1033$ and $550 \mathrm{kN}$, respectively.

\subsection{Gap opening and PT force}

The uplift time histories of RCBF and RZBF under G4 record are presented in Fig. 14. Gap opening is defined as relative displacement between bearing of column and column base. The maximum value of gap opening for $\mathrm{RCBF}$ and RZBF is 27.43 and $32.1 \mathrm{~mm}$. According to the results RZBFs experience larger uplift comparing with RCBFs. The maximum uplift which RZBF experienced is $17 \%$ larger than the value for $\mathrm{RCBF}$. The results show that by increasing gap opening, the roof drift ratio increases. This outcome is consistent with the results of previous relevant studies [56]. As noted previously, ED elements have a reduction effects on the gap opening response. Gap opening time histories are in consistent with the roof $\mathrm{drift}$ time histories.

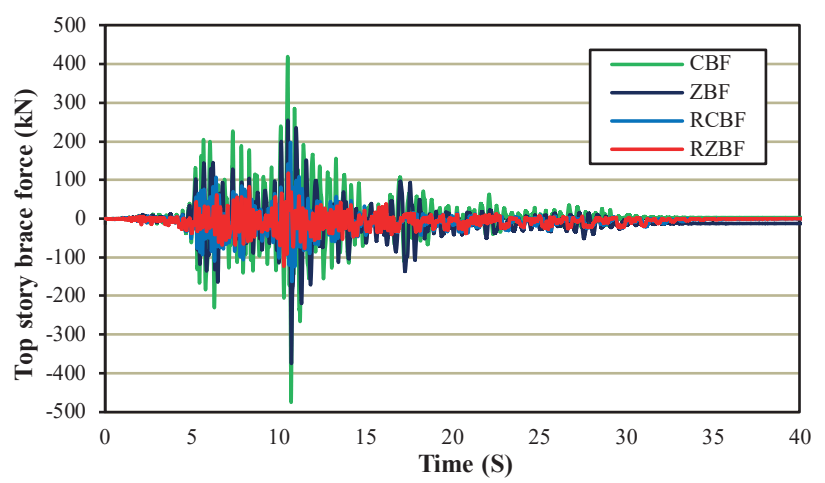

Fig. 13 Comparison of top story braces force time histories of different archetypes $(\mathrm{kN})$

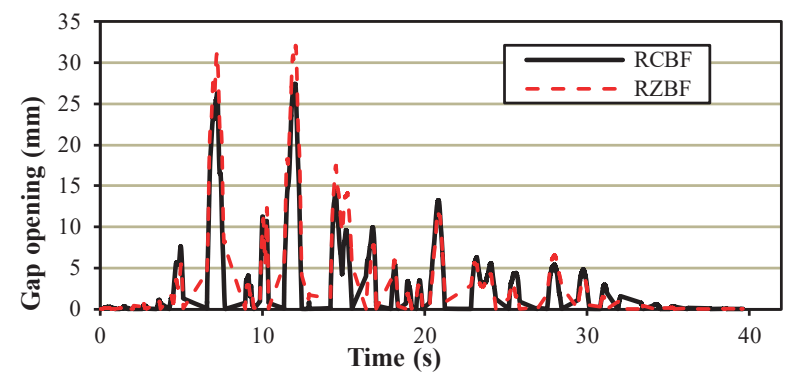

Fig. 14 Rocking systems gap opening time histories under G4 record
Fig. 15 shows a combined time history response of PT force and gap opening for RCBF and RZBF. The maximum values of PT force and gap opening occur at the same time. In other words, the PT forces are in phase with gap opening for both rocking frames, which is similar to Roke et al. findings [41, 42]. The maximum PT force for RCBF and RZBF is about $0.5 \mathrm{Tu}$ and $0.41 \mathrm{Tu}$, respectively. RZBF has the smaller PT force and larger column uplift comparing with RCBF. Zipper columns help to redistribute the unbalance force over the height of the frame and as a result the PT force reduces.

\section{Conclusions}

One of the most widely utilized lateral load resisting systems is Concentrically Braced Frame (CBF). Due to limited lateral displacement capacity of $\mathrm{CBF}$, this system had been experienced soft story mechanism under severe earthquakes. Rocking frames can improve this deficiency. This study proposed using zipper columns along with rocking behavior to improve the Rocking Concentrically Braced Frame (RCBF). So, a comparison study was conducted in order to illustrate the effectiveness of the proposed Rocking Zipper Braced Frames (RZBF). Four different configurations, such as CBF, Zipper Braced Frame $(\mathrm{ZBF}), \mathrm{RCBF}$ and new rocking system, Rocking Zipper Braced Frame (RZBF), were designed and modeled in OpenSees. Nonlinear time history analysis was conducted to assess their seismic performance, subjecting the frames to different ground motions. The main results are drawn as follows:

- Rocking frames have lower residual drift comparing with $\mathrm{CBF}$ and $\mathrm{ZBF}$, which indicate the self-centering behavior of these systems. However, due to the softening behavior, RZBF has the largest peak roof drift ratio comparing with the other systems.
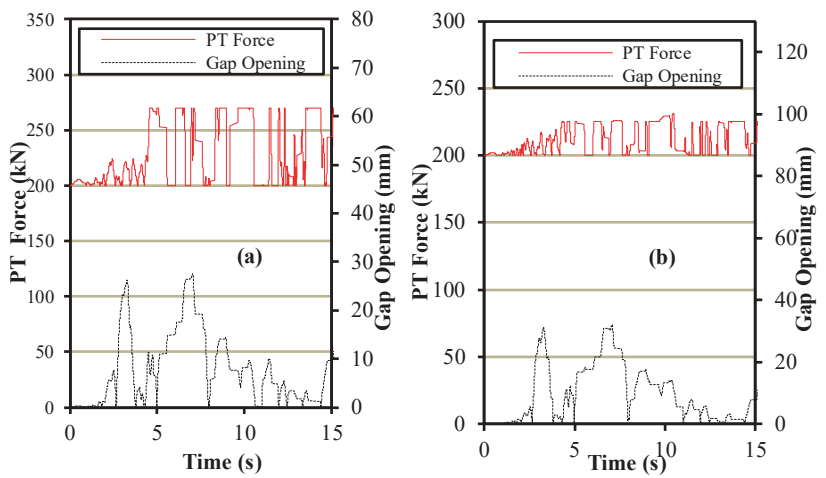

Fig. 15 PT bar force and gap opening time histories of rocking frames under G4 record (a) RCBF system, (b) RZBF system 
- The amount of column uplift in RZBF is $17 \%$ larger than the RCBF column uplift. With increasing the value of column uplift, the roof drift ratio increases. RZBF has the largest roof drift ratio.

\section{References}

[1] Yang, C. S., Leon, R. T., DesRoches, R. "Design and behavior of zipper-braced frames", Engineering Structures, 30(4), pp. 10921100, 2008

https://doi.org/10.1016/j.engstruct.2007.06.010

[2] Merczel, D. B., Somja, H., Aribert, J. M., Lógó, J. "On the behaviour of concentrically braced frames subjected to seismic loading", Periodica Polytechnica Civil Engineering, 57(2), pp. 113-122, 2013.

https://doi.org/10.3311/PPci.7167

[3] Costanzo, S., D'Aniello, M., Landolfo, R., de Martino, A. "Critical discussion on seismic design criteria for cross concentrcially braced frames", Ingegneria Sismica, 2(35), pp. 23-36, 2018.

[4] Costanzo, S., D'Aniello, M., Landolfo, R. "Critical review of seismic design criteria for chevron concentrically braced frames: The role of the brace-intercepted beam", Ingegneria Sismica: International Journal of Earthquake Engineering, 1, pp. 1-2, 2016.

[5] Longo, A., Montuori, R., Piluso, V. "Moment frames-concentrically braced frames dual systems: analysis of different design criteria", Structure and Infrastructure Engineering, 12(1), pp. 122-141, 2016. https://doi.org/10.1080/15732479.2014.996164

[6] Giugliano, M. T., Longo, A., Montuori, R., Piluso, V. "Plastic design of CB-frames with reduced section solution for bracing members", Journal of Constructional Steel Research, 66(5), pp. 611-621, 2010. https://doi.org/10.1016/j.jcsr.2010.01.001

[7] Fahnestock, L. A., Sause, R., Ricles, J. M., Lu, L. W. "Ductility demands on buckling-restrained braced frames under earthquake loading", Earthquake Engineering and Engineering Vibration, 2(2), pp. $255-268,2003$. https://doi.org/10.1007/s11803-003-0009-5

[8] Rezazadeh, F., Mirghaderi, R., Hosseini, A., Talatahari, S. "Optimum energy-based design of BRB frames using nonlinear response history analysis", Structural and Multidisciplinary Optimization, 57(3), pp. 1005-1019, 2018. https://doi.org/10.1007/s00158-017-1791-4

[9] Yang, C. S., Leon, R. T., DesRoches, R. "Pushover Response of a Braced Frame with Suspended Zipper Struts", Journal of Structural Engineering, 134(10), pp. 1619-1626, 2008. https://doi.org/10.1061/(ASCE)0733-9445(2008)134:10(1619)

[10] Roke, D., Sause, R., Ricles, J. M., Gonner, N. "Design Concepts for Damage-Free Seismic-Resistant Self-Centering Steel Concentrically Braced Frames", Presented at: Structures Congress 2009: Don't Mess with Structural Engineers: Expanding Our Role, Austin, TX, USA, 2009, pp. 1-10. https://doi.org/10.1061/41031(341)155
- Adding zipper columns along with rocking behavior reduce the force of top story braces in RZBF system, reduce the PT bars forces and redistribute the unbalance force over the height of frames. The reduction of PT bar force is about $14 \%$.

[11] Wiebe, L., Christopoulos, C., Tremblay, R., Leclerc, M. "Mechanisms to limit higher mode effects in a controlled rocking steel frame. 1: Concept, modelling, and low-amplitude shake table testing", Earthquake Engineering \& Structural Dynamics, 42(7), pp. 1053-1068, 2013.

https://doi.org/10.1002/eqe.2259

[12] European Committee for Standardization (CEN) "EN1998-1-1, Eurocode 8: Design of structures for earthquake resistance - Part 1: General rules, seismic actions and rules for buildings", European Committee for Standardization (CEN), Brussels, Belgium, 2005.

[13] American Institute of Steel Construction (AISC) "ANSI/AISC 34110, Seismic Provisions for Structural Steel Buildings", American Institute of Steel Construction, Chicago, IL, USA, 2010.

[14] Merczel, D. B., Aribert, J. M., Somja, H., Hjiaj, M., Lógó, J. "On the weak storey behaviour of concentrically braced frames", presented at: 8th International Conference on Behavior of Steel Structures in Seismic Areas (STESSA), Shanghai, China, 2015, pp. 1-8.

[15] Merczel, D. B., Aribert, J. M., Somja, H., Hjiaj, M. "Plastic analysis-based seismic design method to control the weak storey behaviour of concentrically braced steel frames", Journal of Constructional Steel Research, 125, pp. 142-163, 2016. https://doi.org/10.1016/j.jcsr.2016.05.008

[16] Naghavi, M., Rahnavard, R., Thomas, R. J., Malekinejad, M. "Numerical evaluation of the hysteretic behavior of concentrically braced frames and buckling restrained brace frame systems", Journal of Building Engineering, 22, pp. 415-428, 2019. https://oi.org/10.1016/j.jobe.2018.12.023

[17] Sabelli, R., Mahin, S., Chang, C. "Seismic demands on steel braced frame buildings with buckling-restrained braces", Engineering Structures, 25(5), pp. 655-666, 2003. https://doi.org/10.1016/S0141-0296(02)00175-X

[18] Kiggins, S., Uang, C. M. "Reducing residual drift of buckling-restrained braced frames as a dual system", Engineering Structures, 28(11), pp. 1525-1532, 2006. https://doi.org/10.1016/j.engstruct.2005.10.023

[19] Ariyaratana, C., Fahnestock, L. A. "Evaluation of buckling-restrained braced frame seismic performance considering reserve strength", Engineering Structures, 33(1), pp. 77-89, 2011. https://doi.org/10.1016/j.engstruct.2010.09.020

[20] Qiu, C., Zhang, Y., Li, H., Qu, B., Hou, H., Tian, L. "Seismic performance of Concentrically Braced Frames with non-buckling braces: A comparative study", Engineering Structures, 154, pp. 93-102, 2018. https://doi.org/10.1016/j.engstruct.2017.10.075

[21] Hoveidae, N. "Numerical Investigation of Seismic Response of Hybrid Buckling Restrained Braced Frames", Periodica Polytechnica Civil Engineering, 63(1), pp. 130-140, 2019. https://doi.org/10.3311/PPci.12040 
[22] Khatib, I. F., Mahin, S. A., Pister, K. S. "Seismic behavior of concentrically braced steel frames", Earthquake Engineering Research Center, University of California, Berkeley, CA, USA, Rep. UCB/ EERC-88/01, 1988.

[23] Sabelli, R. "Research on improving the design and analysis of earthquake-resistant steel-braced frames", The 2000 NEHRP Professional Fellowship Report, EERI, Oakland, CA, USA, Rep. PF2000-9, 2001. [online] Available at: https://www.eeri.org/wp-content/uploads/ 2000.Sabelli.Prof_.Fellow.Rpt_pdf [Accessed: 15 January 2020]

[24] Tremblay, R., Tirca, L. "Behavior and design of multi-storey zipper concentrically braced steel frames for the mitigation of soft-storey response", In: Proceedings of the Conference on Behavior of Steel Structures in Seismic Area, Naples, Italy, 2003, pp. 471-478.

[25] Tirca, L., Tremblay, R. "Influence of Building Height and Ground Motion Type on the Seismic Behavior of Zipper Concentrically Braced Steel Frames", In: 13th World Conference on Earthquake Engineering, Vancouver, Canada, 2004, Article Number: 2894.

[26] Tirca, L., Tremblay, R. "Incremental dynamic analysis of multistorey concentrically braced steel frames", In: Mazzolani, F., Ricles, J. M., Sause, R. (eds.) Behaviour of Steel Structures in Seismic Areas, STESSA 2009, CRC Press, Boca Raton, FL, USA, 2009, pp. 359-367. https://doi.org/10.1201/9780203861592.ch51

[27] Ozcelik, Y., Saritas, A., Clayton, P. M. "Comparison of chevron and suspended-zipper braced steel frames", Journal of Constructional Steel Research, 119, pp. 169-175, 2016. https://doi.org/10.1016/j.jcsr.2015.12.019

[28] Huckelbridge, A. A. "Earthquake simulation tests of a nine story steel frame with columns allowed to uplift", Earthquake Engineering Research Center, College of Engineering, University of California, Berkeley, CA, USA, Rep. UCB/EERC-77/23, 1977.

[29] Kelly, J. M., Tsztoo, D. F. "Earthquake simulation testing of a stepping frame with energy-absorbing devices", Earthquake Engineering Research Center, College of Engineering, University of California, Berkeley, CA, USA, Rep. UCB/EERC-77/17, 1977.

[30] Eatherton, M. R., Ma, X., Krawinkler, H., Deierlein, G .G., Hajjar, J. F. "Quasi-Static Cyclic Behavior of Controlled Rocking Steel Frames", Journal of Structural Engineering, 140(11), Article Number: 04014083, 2014. https://doi.org/10.1061/(ASCE)ST.1943-541X.0001005

[31] Eatherton, M., Hajjar, J., Deierlein, G., Ma, X., Krawinkler, H. "Hybrid simulation testing of a controlled rocking steel braced frame system", presented at 9th U.S. National and 10th Canadian Conference on Earthquake Engineering, Ontario, Canada, Article Number: 734, July, 25-29, 2010.

[32] Wu, D., Lu, X. L. "Structural performance evaluation of a new energy-dissipation and light-weight rocking frame by numerical analysis and experiment", presented at Proceedings of the 10th Pacific Conference on Earthquake Engineering Building and EarthquakeResilient Pacific, Sydney, Australia, Article Number: 191, Nov, 6-8, 2015. [online] Available at: http://aees.org.au/wp-content/ uploads/2015/12/Paper_191.pdf [Accessed: 15 January 202]

[33] Blebo, F. C., Roke, D. A. "Seismic-resistant self-centering rocking core system", Engineering Structures, 101, pp. 193-204, 2015. https://doi.org/10.1016/j.engstruct.2015.07.016
[34] Blebo, F. C., Roke, D. A. "Seismic-resistant self-centering rocking core system with buckling restrained columns", Engineering Structures, 173, pp. 372-382, 2018. https://doi.org/10.1016/j.engstruct.2018.06.117

[35] Grigorian, M., Grigorian, C. "An introduction to the structural design of rocking wall-frames with a view to collapse prevention, self-alignment and repairability", The Structural Design of Tall and Special Buildings, 25(2), pp. 93-111, 2016. https://doi.org/10.1002/tal.1230

[36] Mottier, P., Tremblay, R. Rogers, C. "Seismic retrofit of low-rise steel buildings in Canada using rocking steel braced frames", Earthquake Engineering \& Structural Dynamics, 47(2), pp. 333-355, 2018. https://doi.org/10.1002/eqe.2953

[37] Jia, L. J., Li, R. W., Xiang, P., Zhou, D. Y., Dong, Y. "Resilient steel frames installed with self-centering dual-steel buckling-restrained brace", Journal of Constructional Steel Research, 149, pp. 95-104, 2018. https://doi.org/10.1016/j.jcsr.2018.07.001

[38] Moradi, S., Burton, H. V. "Response surface analysis and optimization of controlled rocking steel braced frames", Bulletin of Earthquake Engineering, 16(10), pp. 4861-4892, 2018. https://doi.org/10.1007/s10518-018-0373-1

[39] Dyanati, M., Huang, Q., Roke, D. "Cost-benefit evaluation of self-centring concentrically braced frames considering uncertainties", Structure and Infrastructure Engineering, Maintenance, Management, Life-Cycle Design and Performance, 13(5), pp. 537553, 2017. https://doi.org/10.1080/15732479.2016.1173070

[40] Dyanati, M., Huang, Q., Roke, D. "Seismic demand models and performance evaluation of self-centering and conventional concentrically braced frames", Engineering Structures, 84, pp. 368-381, 2015. https://doi.org/10.1016/j.engstruct.2014.11.036

[41] Roke, D., Sause, R., Ricles, J. M., Seo, C. Y., Lee, K. S. "Selfcentering seismic-resistant steel concentrically-braced frames", presented at 8th US National Conference on Earthquake Engineering (EERI), San Francisco, CA, USA, April, 18-22, 2006.

[42] Roke, D. A., Hasan, M. R. "The Effect of Frame Geometry on the Seismic Response of Self-Centering Concentrically-Braced Frames", International Journal of Civil and Environmental Engineering, 6, pp. 140-145, 2012.

[43] Rahgozar, N., Moghadam, A. S., Rahgozar, N., Aziminejad, A. "Performance evaluation of self-centring steel-braced frame", Proceedings of the Institution of Civil Engineers-Structures and Buildings, 170(1), pp. 3-16, 2017. https://doi.org/10.1680/jstbu.15.00136

[44] Rahgozar, N., Moghadam, A. S., Aziminejad, A. "Quantification of seismic performance factors for self-centering controlled rocking special concentrically braced frame", The Structural Design of Tall and Special Buildings, 25(14), pp. 700-723, 2016. https://doi.org/10.1002/tal.1279

[45] Chancellor, N. B. "Seismic Design and Performance of SelfCentering Concentrically-Braced Frames", Ph.D. Thesis, Lehigh University, 2014. 
[46] Hu, S., Wang, W., Qu, B. "Enhancing seismic performance of tension-only concentrically braced beam-through frames through implementation of rocking cores", Engineering Structures, 169, pp. 68-80, 2018.

https://doi.org/10.1016/j.engstruct.2018.05.035

[47] Huang, Q., Dyanati, M., Roke, D. A., Chandra, A., Sett, K. "Economic Feasibility Study of Self-Centering Concentrically Braced Frame Systems", Journal of Structural Engineering, 144(8), Article Number: 04018101, 2018.

https://doi.org/10.1061/(ASCE)ST.1943-541X.0002093

[48] McKenna, F., Fenves, G. L., Scott, M. H. "Open system for earthquake engineering simulation", Pacific Earthquake Engineering Research Center, University of California, Berkeley, CA, USA, 2000.

[49] American Institute of Steel Construction (AISC) "ANSI/AISC 36010, Specification for Structural Steel Buildings", American Institute of Steel Construction, Chicago, IL, USA, 2010.

[50] Liu, J., Astaneh-Asl, A. "Moment-Rotation Parameters for Composite Shear Tab Connections", Journal of Structural Engineering, 130(9), pp. 1371-1380, 2004. https://doi.org/10.1061/(ASCE)0733-9445(2004)130:9(1371)

[51] Gunnarsson, I. R. "Numerical performance evaluation of braced frame systems", Doctoral dissertation, University of Washington, 2004.
[52] Hsiao, P. C., Lehman, D. E., Roeder, C. W. "A model to simulate special concentrically braced frames beyond brace fracture", Earthquake Engineering \& Structural Dynamics, 42(2), pp. 183200, 2013.

https://doi.org/10.1002/eqe.2202

[53] Hsiao, P. C., Lehman, D. E., Roeder, C. W. "Improved analytical model for special concentrically braced frames", Journal of Constructional Steel Research, 73, pp. 80-94, 2012. https://doi.org/10.1016/j.jcsr.2012.01.010

[54] Uriz, P., Mahin, S. A. "Toward Earthquake-Resistant Design of Concentrically Braced Steel-Frame Structures", Pacific Earthquake Engineering Research Center, College of Engineering University of California, Berkeley, CA, USA, Rep. 2008/08, 2008.

[55] Seo, C. "Influence of ground motion characteristics and structural parameters on seismic responses of SDOF systems", Ph.D. Thesis, Lehigh University, 2005.

[56] Sause, R., Ricles, J. M., Roke, D. A., Chancellor, N. B., Gonner, N. P. "Large-Scale Experimental Studies of Damage-Free SelfCentering Concentrically-Braced Frame under Seismic Loading", In: Structures Congress 2010, Orlando, FL, USA, 2010, pp. 1498-1509.

https://doi.org/10.1061/41130(369)136 